\title{
Évolution technique et mutations de l'habitat
}

\section{Christian Zarka}

\section{OpenEdition}

Journals

Édition électronique

URL : https://journals.openedition.org/tc/1022

DOI : $10.4000 /$ tc. 1022

ISSN : 1952-420X

\section{Éditeur}

Éditions de l'EHESS

\section{Édition imprimée}

Date de publication : 1 septembre 1983

ISSN : 0248-6016

\section{Référence électronique}

Christian Zarka, «Évolution technique et mutations de l'habitat», Techniques \& Culture [En ligne], 2 I

1983, mis en ligne le 26 janvier 2006, consulté le 29 septembre 2022. URL : http://

journals.openedition.org/tc/1022 ; DOI : https://doi.org/10.4000/tc.1022

Ce document a été généré automatiquement le 29 septembre 2022

Tous droits réservés 
Évolution technique et mutations de l'habitat

Christian Zarka 